\title{
Dohányzói életutak magyar serdülők körében
}

\author{
Pénzes Melinda dr. ${ }^{1}$ - Czeglédi Edit dr. ${ }^{2}$ \\ Balázs Péter dr. ${ }^{1}$ - Urbán Róbert dr. ${ }^{3}$ \\ Semmelweis Egyetem, Általános Orvostudományi Kar, ${ }^{1}$ Népegészségtani Intézet, \\ ${ }^{2}$ Magatartástudományi Intézet, Budapest \\ ${ }^{3}$ Eötvös Loránd Tudományegyetem, Pedagógiai és Pszichológiai Kar, Pszichológiai Intézet, \\ Személyiség- és Egészségpszichológiai Tanszék, Budapest
}

\begin{abstract}
Bevezetés: A serdülőkori dohányzói életutak jellemzőinek ismerete elengedhetetlen a hatékony dohányzásprevenciós programok tervezéséhez. Célkitüzés: Longitudinális vizsgálattal azonosítani a serdülők cigarettahasználatának változásait, valamint a dohányzói életutak alakulásában szerepet játszó kockázati tényezőket. Módszer: Hároméves, évenkénti adatgyüjtéssel folytatott kutatásunkat nagyvárosi serdülők $(\mathrm{n}=1092)$ két életkori kohorszában $(6$. és 9 . iskolai évfolyam) végeztük, önkitöltôs kérdőíves módszerrel. A cigarettahasználati adatok alapján öt dohányzói életútcsoportot határoztunk meg. Eredmények: A minta 67,5\%-a megőrizte nem dohányzó magatartását, 11,3\%-a mindvégig dohányzott, 14,3\%-a rászokott, 3,3\%-a leszokott, 3,7\%-a kísérletezó maradt. Az egyes dohányzói életútcsoportba tartozók jelentősen különböztek egymástól a cigarettázó barátok száma, szülőii dohányzás, családszerkezet, tanulmányi eredmény és heti zsebpénz kiindulási vizsgálatban tapasztalt jellemzői alapján. Következtetések: A serdülők nem kezelhetők homogén populációként a dohányzást megelőző programokban, mert különböző dohányzó magatartású csoportjaikban eltérő kockázati tényezők kerülnek előtérbe. Orv. Hetil., 2017, 158(2), 67-76.
\end{abstract}

Kulcsszavak: serdülőkor, dohányzás, longitudinális kutatás, prevenció

\section{Smoking trajectories among Hungarian adolescents}

Introduction: Understanding adolescent smoking trajectories is necessary for tailored prevention programs. Aim: To identify adolescent cigarette use patterns and risk factors of smoking trajectories by a longitudinal study. Method: We conducted a three-year prospective survey in two age cohorts (6th and 9th school grades) of metropolitan adolescents $(\mathrm{n}=1,092)$ with yearly data collection by self-administered questionnaires. Five smoking trajectory groups were defined by cigarette smoking data. Results: $67.5 \%$ of the sample remained nonsmoker, $11.3 \%$ smoked all the time, $14.3 \%$ were initiators, $3.3 \%$ quitters and $3.7 \%$ experimenters. Members of smoking trajectory groups differed significantly from each other according to number of smoking friends, parental smoking, family structure, academic achievement and weekly allowance at baseline. Conclusions: Concerning tobacco prevention programs, adolescents are not homogenous population, because distinct set of risk factors are highlighted in their different smoking behavior groups.

Keywords: adolescence, smoking, longitudinal survey, prevention

Pénzes, M., Czeglédi, E., Balázs, P., Urbán, R., [Smoking trajectories among Hungarian adolescents]. Orv. Hetil., $2017,158(2), 67-76$.

(Beérkezett: 2016. szeptember 30.; elfogadva: 2016. november 9.)

\section{Rövidítések}

$\mathrm{T} 1$ = (time 1$)$ első adatfelvétel; T2 = (time 2$)$ második adatfelvétel; T3 = (time 3 ) harmadik adatfelvétel; TTM = transzteoretikus modell
A dohányzás kialakulása és megszilárdulása összetett folyamat serdülőkorban, amely heteken, hónapokon vagy akár éveken keresztül zajlik [1]. Kezdetben szakaszokból 
álló jelenségként kezelte a szakirodalom, később, a modern statisztikai módszerek révén, fejlődési folyamatként kezdték értelmezni. Jelenleg a serdülőkori dohányzás jelenségének kétféle megközelítési módja lehetséges [2]:

1. Dobányzási szakaszok modellje, amely a dohányzás változását szakaszokra osztja. Egyes modellek viselkedési, illetve motivációs fázisokat használnak, mások a kettő kombinációjára épülnek.

2. Dohányzói életutak (trajektóriák, karrierek) modellje, amely a serdülőkori dohányzást időben előrehaladó fejlődési folyamatként értelmezi, és a dohányzás elkezdésében, illetve a dohányzó-magatartás változásában interperszonális különbségeket feltételez. A különböző életutak meghatározásához több, legalább három időpontban szükséges vizsgálni a dohányzói magatartást, ami lehetővé teszi az időben hasonló magatartás-változást mutató egyének csoportosítását [2].

A dohányzás mint több szakaszban kialakuló komplex viselkedés felvázolása elsőként 1980-ban fogalmazódott meg a szakirodalomban [3]. Az azóta eltelt évtizedekben a serdülők körében végzett longitudinális kutatások többféle fázist azonosítottak $[1,4,5]$. A viselkedési szakaszokra épülő elméletek közül Flay (1993) ötlépcsős modelljét érdemes kiemelni:

1. Előkészületi állapot: A fiatalok dohányzással kapcsolatos ismeretei, elvárásai, hiedelmei körvonalazódnak.

2. Kipróbálás: Próbálkozás néhány alkalommal a dohányzással, az ekkor tapasztalt élettani hatások, pszichoszociális megerôsítések fogják meghatározni, hogy a későbbiekben a serdülő átlép-e a következő szakaszokba.

3. Kísérletezés: Évekig is elhúzódhat, a dohányzás nem rendszeres, elsősorban társas helyzetekre korlátozódik.

4. Rendszeres használat: Kezdetben heti, majd napi gyakorisággal, egyre többféle élethelyzetben.

5. Létrejön a nikotinfüggőség [4].

A serdülőkori dohányzás kialakulásának különböző motivációs szakaszaiban az egyének megkülönböztetésére jól alkalmazható a viselkedésváltozás transzteoretikus modellje (TTM) $[1,6]$. A TTM-et eredetileg addiktológiai problémákkal küzdő felnőttek leszokásának segítésében használták sikeresen, azonban az utóbbi évtizedekben egyre kiterjedtebben alkalmazzák számos egészségre kedvező, illetve káros magatartás elfogadási folyamatának jellemzésére $[7,8]$. A TTM alapján a viselkedésváltozás - jelen esetben a dohányzásra rászokás szakaszosan következik be, és az egyes fázisokban lévő egyéneket eltérő kognitív és magatartásbeli minták jellemzik [6]. A viselkedésváltozás többnyire hosszú időtartam alatt, öt lépésben zajlik:

1. Fontolgatás előtti időszak.

2. Fontolgatás időszaka.

3. Előkészület.

4. Cselekvés.

5. Fenntartás [8].

A serdülőkori dohányzás kialakulásának korai fázisában a dohányzásra való fogékonyság modellje is alkal- mazható, amely a még nem dohányzó fiatalokat csoportosítja a jövő́beni dohányzás szándéka alapján [9]. A TTM és a dohányzásra való fogékonysági modell ötvözése során a töprengés előtti fázis további két időszakkal, a jövőbeni dohányzásra nem fogékony, illetve fogékony stádiumokkal bővül [6]. A dohányzás kialakulásának alapvető, előbbiekben vázolt modelljeiből Mayhew és $m t s a i$ egy könnyen átlátható, hatlépcsős, összetett serdülőkori modellt készítettek:

1. Soha nem dohányzók, és nem is tervezik azt.

2. Soha nem dohányzók, de már fontolgatják a megkezdését.

3. Kipróbálók.

4. Kísérletezők.

5. Rendszeres használók.

6. Stabil, napi dohányosok [5].

Manapság teljes az egyetértés abban, hogy a serdülőkor kritikus időszak a dohányzás elkezdésének és előrehaladásának szempontjából, jóllehet, kevésbé ismertek a dohányzó-magatartás kibontakozásának időbeli különbségei [10]. Serdülőkorban a fiatalok általában áthaladnak a dohányzás fenti szakaszain, azonban az eddigi kutatások alapján úgy tưnik, hogy ez a folyamat egyes csoportjaikban eltérő mintázatú [11]. Miután a statisztikai módszerek fejlődése lehetőséget nyitott a dohányzói életutak elemzésére, nemcsak a különböző dohányzói magatartások azonosíthatók, hanem a dohányzási szokások időbeni egyéni változásai és az egyes életutak prediktorai is vizsgálhatóvá váltak [1]. A hasonló dohányzói életutakat mutató csoportok meghatározása általában a cigarettázás gyakorisága és intenzitása alapján történik [1]. Az elmúlt másfél évtizedben végzett kutatások számos serdülőkori dohányzói magatartás-mintázatot azonosítottak (1. táblázat), amelyekben a dohányzói életútcsoportok eltérő számát és heterogén megjelenését egyértelmüen a módszertani korlátok magyarázzák [10-17]. Az eltérések egyrészt a különböző mintaméretekből adódhatnak, ugyanis minél kisebb a minta, annál valószínúbb, hogy kevesebb lesz az életútcsoportok száma. Emellett a követés időtartama, a minta reprezentativitása, a dohányzás mérésének különbségei szintén hatással lehetnek az azonosított dohányzói életutakra, illetve azok általánosíthatóságára [2, 17]. Rövidebb longitudinális vizsgálatok, kisebb mintamérettel és három-öt méréssel, modern statisztikai módszerekkel is legfeljebb négy dohányzói életutat azonosítottak [13, 16], hasonló kutatásokban mások viszont eleve empirikus módon határozták meg az életutakat [15]. A jelenleg korlátozott számú, de a témában egyre gyakrabban megjelenő nemzetközi szakirodalmi közlemények nyilvánvalóvá teszik, hogy a serdülők dohányzása nem azonos időpontban és nem azonos gyakorisággal, illetve intenzitással kezdődik [13]. A homogén dohányzói alcsoportok azonosítása a hasonló longitudinális cigarettázási mintázatok alapján segítséget nyújthat a dohányzó-magatartás etiológiájának megértéséhez és a magas kockázatú alcsoportok feltárásához [10]. Mindez lehetőséget biztosít a dohányzás 
1. táblázat | Dohányzói életutak szisztematikus összehasonlítása Park és June javaslata alapján [2]

\begin{tabular}{|c|c|c|c|}
\hline $\begin{array}{l}\text { Közlemény szerzője } \\
\text { (évszám) }\end{array}$ & $\begin{array}{l}\text { A minta életkori } \\
\text { tartománya (év) }\end{array}$ & $\begin{array}{l}\text { Követés időtartama } \\
\text { (mérések száma) }\end{array}$ & Dohányzói életútcsoportok \\
\hline Colder és mtsai (2001) & $12-16$ & 6 év (6) & $\begin{array}{l}\text { 1. Korai gyors fokozók (eszkalátorok) } \\
\text { 2. Késői mérsékelt eszkalátorok } \\
\text { 3. Késői lassú eszkalátorok } \\
\text { 4. Stabil enyhe („light”) dohányzók } \\
\text { 5. Stabil alkalmi dohányzók }\end{array}$ \\
\hline White és mtsai (2002) & $12-30$ & 18 év (5) & $\begin{array}{l}\text { 1. Nem dohányzók/kísérletezők } \\
\text { 2. Alkalmi dohányzók/már nem használók } \\
\text { 3. Erős/rendszeres dohányzók }\end{array}$ \\
\hline $\begin{array}{l}\text { Audrain-McGovern és } \\
\text { mtsai }(2004)\end{array}$ & $14-18$ & 3 év (5) & $\begin{array}{l}\text { 1. Korai/gyors rászokók } \\
\text { 2. Késői/lassú rászokók } \\
\text { 3. Kísérletezők } \\
\text { 4. Soha nem dohányzók }\end{array}$ \\
\hline Karp és mtsai (2005) & $12-17$ & 3,5 év (14) & $\begin{array}{l}\text { 1. Rászokáskor a dohányzás intenzitása alacsony, az intenzitás } \\
\text { fokozatosan emelkedik } \\
\text { 2. Rászokáskor a dohányzás intenzitása alacsony, az intenzitás idővel } \\
\text { exponenciálisan emelkedik } \\
\text { 3. Rászokáskor a dohányzás intenzitása alacsony, majd legnagyobb } \\
\text { intenzitású két évvel később, ez után pedig csökken } \\
\text { 4. Rászokáskor a dohányzás intenzitása viszonylag magas, és később } \\
\text { is magasabb marad, mint a többi csoportban }\end{array}$ \\
\hline Stice és Martinez (2005) & $11-18$ & 3 év (3) & $\begin{array}{l}\text { 1. Tartósan nem dohányzók } \\
\text { 2. Dohányzásra rászokók } \\
\text { 3. Dohányzásról leszokók } \\
\text { 4. Tartósan dohányzók }\end{array}$ \\
\hline Bernat és mtsai (2008) & $12-16$ & 3 év (6) & $\begin{array}{l}\text { 1. Nem dohányzók } \\
\text { 2. Kipróbálók } \\
\text { 3. Alkalmi használók } \\
\text { 4. Korai stabil dohányzók } \\
\text { 5. Késői stabil dohányzók } \\
\text { 6. Dohányzást mérséklők }\end{array}$ \\
\hline Xie és mtsai (2013) & $12-16$ & 3 év (3) & $\begin{array}{l}\text { 1. Nem dohányzók } \\
\text { 2. Stabil enyhe/alkalmi dohányzók } \\
\text { 3. Dohányzást gyorsan fokozók }\end{array}$ \\
\hline $\begin{array}{l}\text { Fuemmeler és mtsai } \\
(2013)\end{array}$ & $13-32$ & 14 év (4) & $\begin{array}{l}\text { 1. Nem használók } \\
\text { 2. Könnyü („light”) használók } \\
\text { 3. Korai használók } \\
\text { 4. Késôi használók } \\
\text { 5. Késối, erôs használók }\end{array}$ \\
\hline
\end{tabular}

célzott prevenciójára, vagyis arra, hogy a serdülők mely csoportját, milyen típusú (például primer vagy szekunder) prevenciós programmal, mikor és milyen tényezők hangsúlyozásával érdemes megcélozni [13].

Magyarországon eddig túlnyomórészt keresztmetszeti kutatások alapján ismertük a serdülőkorúak dohányzási szokásainak változását, azonban ez a módszer alkalmatlan a dohányzói életutak vizsgálatára [18-20]. Tudomásunk szerint jelen kutatás mellett csak egy követéses vizsgálat, a Budapesti Serdülőkori Dohányzás Kutatás készült a témában, amely a fóvárosi serdülők egy szükebb korcsoportjára korlátozódott [21]. Mindezek miatt szükségesnek láttuk, hogy a hazai serdülők szélesebb körében longitudinális vizsgálattal azonosítsuk a cigarettahasználat változásait, valamint feltárjuk a dohányzói életutak alakulásában feltehetően szerepet játszó egyes kockázati tényezők (tanulmányi eredmény, zsebpénz, családszerkezet, barátok dohányzása, szülői dohányzás) jelentőségét.

\section{Módszer}

\section{Résztvevớk és az eljárás menete}

A hároméves, évenként egyszeri adatgyưjjtéssel végzett prospektív kohorszvizsgálatunk a 2009-2010. iskolai tanévben kezdődött Budapesten és öt magyar nagyvárosban (Debrecen, Győr, Miskolc, Pécs, Szeged), 6. és 9. évfolyamos tanulók körében. A Közoktatási Információs Iroda 2008. évi adatai alapján a fenti városokban kettős rétegzést végeztünk, mind a hatodikos és kilencedikes tanulói létszámok, mind az iskolatípus alapján. Az isko- 
lák kiválasztása - rétegenként a fenti települések összes iskolái közül - randomszám-generálás módszerével történt. Az iskolákat elektronikusan (e-mail) és faxon is tájékoztattuk, illetve kértük fel a vizsgálatban való részvételre. A 413 kiküldött felkérésre 78 iskola (általános, szakközép-, szakiskolák és gimnáziumok) jelezte részvételi szándékát, így 109 osztály 2985 tanulóját vehettük számításba. Szüleik számára írásbeli tájékoztatást küldtünk a kutatásról, és jeleztük, hogy amennyiben nem válaszolnak (passzív beleegyezés), az hozzájárulást jelent gyermekük vizsgálatban való részvételéhez. Ilyen alapon 2567 diákot hívtunk meg a kutatásba. Miután a tanulók számára ismeretlen, előzetesen felkészített adatgyüjtő munkatársaink szóban és írásban is tájékoztatták a diákokat a vizsgálatban való részvétel önkéntességéről, papíralapú kérdőíveinket egy-egy iskolai tanóra keretében töltötték ki. Akik vállalták a követéses vizsgálatban való részvételt, a három adatfelvételkor iskolájuk nevét és saját nevüket vagy jeligéjüket, illetve évfolyamukat az önkitöltős kérdő́ív első oldalán tüntették fel. Az adatbevitelt megelőzően ezeket az információkat anonim kóddá alakítottuk át, a hozzájuk tartozó elektronikus adattárat (nevekkel és kódokkal) pedig a kérdőív adataitól elkülönítve tároltuk. Kutatásetikai engedélyünket a Semmelweis Egyetem Regionális, Intézményi Tudományos és Kutatásetikai Bizottsága adta (TUKEB 104/2009).

Az első adatfelvétel (time 1 - Tl) 2009. november és 2010. március között történt, amely során 2208 értékelhető kérdőív érkezett vissza. A második adatfelvétel (time 2 - T2) időszaka 2010. december és 2011. március közé ( $\mathrm{n}=2081)$, a harmadik (time 3 - T3) pedig 2012. január és május közé esett $(\mathrm{n}=1987)$. A vizsgálat prospektív természetéból adódó lemorzsolódás miatt a kiindulási minta 49,5\%-át $(\mathrm{n}=1092)$ sikerült három éven keresztül követni.

\section{Mérőeszközök}

\section{Szociodemográfiai változók}

A résztvevők mindegyik adatfelvétel során megjelölték a nemüket (fiú/lány), betöltött életkorukat években, iskolai évfolyamukat. Ez utóbbi az általános iskolai résztvevőknél 6., 7. és 8. évfolyam (fiatalabb kohorsz, $n=467$ ), míg a középiskolásoknál 9., 10. és 11 . évfolyam (idősebb kohorsz, $\mathrm{n}=625$ ) volt.

Családszerkezetükről (otthonukban kikkel élnek együtt) szintén mindegyik mérés során beszámoltak, amely alapján intakt, újrastrukturált család, valamint egy édesszülővel vagy egyéb módon együtt élő kategóriák keletkeztek.

A zsebpénz heti átlagos összegét hétfokozatú skálán lehetett jelölni ( $1=$ nem szokott kapni; $2=$ kevesebb mint 500 forint; $3=501-1000 ; 4=1001-1500 ; 5=$ $1501-2000 ; 6=2001-3000 ; 7=$ több mint 3000 fo- rint). Ezt a változót az elemzések során esetenként ordinális skálaként, máshol a medián felezési módszerrel kétértékű változóként kezeltük ( $0=\leq 1000$ forint vagy nem kap zsebpénzt, 1 = $\geq 1001$ forintot kap hetente).

Az egyes vizsgálatokat megelőző félévben elért tanulmányi átlag jelölésére hatfokozatú skála szolgált, amelynek osztályközei 0,5 értékkel emelkedtek 2,00-5,00 tartományban $(1=2,00-2,50 ; 2=2,51-3,00 ; 3=3,01-$ $3,50 ; 4=3,51-4,00 ; 5=4,01-4,50 ; 6=4,51-5,00)$. A tanulmányi eredményt egyes elemzésekben ordinális skálaként, máshol dichotóm kategorikus változóvá alakítva $(0=\leq 3,50 ; 1=\geq 3,51)$ használtuk.

\section{Dohányzást befolyásoló társas hatás változók}

A diákokkal együtt élő édesanya/mostohaanya, illetve édesapa/mostohaapa aktuális dohányzása alapján a válaszokból dichotóm változót képeztünk (egyik szülő sem dohányzik/egyik vagy mindkét szülő dohányzik) [22]. A kortársak dohányzásának hatását a közeli barátok cigarettázásával mértük ( Legjobb barátaid közül hányan szívnak el legalább egy szál cigarettát hetente?”), 0-5-ig terjedő skálán.

\section{Dohányzás}

A cigaretta kipróbálására és az aktuális cigarettázásra adott válaszokból indultunk ki: az elmúlt 30 nap önjellemzős gyakorisági adatai alapján aktuálisan dohányzónak tekintettük azokat, akik az elmúlt hónapban legalább egy napon cigarettáztak $[22,23]$. Az egyes mérési időpontokban néhány tanuló inkoherens módon válaszolt. Így például az önmagukat aktuálisan dohányzónak jelölők egy másik kérdésre azt állították, hogy sohasem próbálták ki a cigarettát, vagy az utánkövetés során a korábban cigarettát kipróbálók nyilatkoztak úgy, hogy ezt sohasem tették. Ezekben az esetekben (T1: 9,3\%; T2: 5,4\%; T3: 7,4\%) mindig a kiindulási választ tekintettük mértékadónak a koherens elemzés érdekében. A longitudinális vizsgálat a dohányzó-magatartás változását is nyomon követhetôvé tette.

Stice és Martinez csoportosítását, valamint a dohányzói életutak szakirodalmát figyelembe véve a résztvevők öt dohányzói életútcsoportba kerülhettek $[2,15]$ :

1. Nem dohányzók: egyik mérési időpontban sem dohányoztak az elmúlt 30 napban.

2. Kísérletezők: a vizsgálat során váltakozva rászoktak vagy leszoktak, és fordítva.

3. Rászokók: T1 méréskor nem, de T2 vagy T3 időpontban már dohányoztak.

4. Leszokók: T1 időpontban dohányoztak, majd T2, illetve T3 méréskor már nem.

5. Dohányzók: mindhárom mérési időpontban dohányoztak. 


\section{Statisztikai elemzés}

$\mathrm{Az}$ adatbevitel és az adatelemzés részben IBM-SPSS v.22, valamint ROPstat 2.0 programcsomagokkal történt [24]. A számítások során szignifikanciaszintnek a $\mathrm{p}<0,05$ értéket, kettőnél több csoport összehasonlítása esetében pedig a Bonferroni-féle korrigált p-értéket fogadtuk el. A leíró statisztikai elemzéseket Pearson-féle $\chi^{2}$-próbával és kétmintás t-próbával végeztük. Az időbeli változások feltárására a kettőnél több összetartozó minta vagy ismételt mérések esetén dichotóm változók eloszlásának összehasonlítására alkalmas Cochran-féle Q-próbát és Friedman-próbát (az ismételt méréses varianciaanalízis nemparaméteres változatát) alkalmaztunk. Az összefüggések vizsgálatát Pearson-féle $\chi^{2}$-próbával és a hatásméret kifejezésére szolgáló Cramer-féle V-érték számításával, valamint Kruskal-Wallis-próbával, vagyis az egyszempontos varianciaanalízis nemparaméteres változatával végeztük.

\section{Eredmények}

\section{A longitudinális minta leiró jellemzôi}

A kiindulási minta felének lemorzsolódása a követéses vizsgálat során torzíthatta az eredményeket. Ennek meghatározása érdekében mindhárom mérési ponton összehasonlítottuk a követettek és a követésből kiesettek min- táit a szociodemográfiai és a dohányzó-magatartás változói mentén. A longitudinális elemzésben részt vevők átlagéletkorukat tekintve fiatalabbak voltak, nagyobb arányban maradtak a vizsgálatban az általános iskolások, a lemorzsolódás jelentősebb mértékű volt a szakközépiskolások és a szakmunkásképzőbe járók körében. Emellett föként a fóvárosi, jobb tanulmányi eredményü, kevesebb zsebpénzzel rendelkező, kiinduláskor jobbára kedvezőbb családszerkezetben élő, a cigarettával kevésbé próbálkozó és dohányzó populációt képviselték a vizsgálatban maradó diákok.

A longitudinális minta kohorszonkénti összehasonlítása (2. táblázat) alapján megállapítható, hogy a fiatalabb kohorszban valamivel kevesebb lányt sikerült követni, mint fiút, az idősebb kohorszban viszont a lányok képviselték a többséget. A fóvárosiak aránya jelentősen nagyobb volt az általános iskolások, mint a középiskolások körében. Három év alatt a jó $(\geq 3,51)$ tanulmányi átlagú diákok aránya szignifikánsan csökkent mind az általános iskolások, mind a középiskolások között. Jelentősen emelkedett az általános iskolásoknál azoknak az aránya, akik hetente több mint 1000 forint zsebpénzt kaptak, míg a középiskolásoknál ez nem volt jellemző. Az intakt családban élő tanulók aránya egyaránt csökkent a fiatalabbaknál és az idősebbeknél is. Egyik vagy mindkét szülő/mostohaszülő dohányzásáról a két kohorsz tagjai hasonló arányban számoltak be és ennek mértéke érdemben nem változott a kutatás során. A legalább heti

2. táblázat |A longitudinális minta két kohorszának leíró jellemzői az egyes vizsgálati időpontokban

\begin{tabular}{|c|c|c|c|c|c|c|c|c|}
\hline \multirow[t]{2}{*}{ Változók } & \multicolumn{4}{|c|}{ Fiatalabb kohorsz $(n=467)$} & \multicolumn{4}{|c|}{ Idősebb kohorsz $(\mathrm{n}=625)$} \\
\hline & $\begin{array}{l}\text { 1. vizsgálat } \\
\text { (T1) } \\
\text { 6. évfolyam }\end{array}$ & $\begin{array}{l}\text { 2. vizsgálat } \\
\text { (T2) } \\
\text { 7. évfolyam }\end{array}$ & $\begin{array}{l}\text { 3. vizsgálat } \\
\text { (T3) } \\
\text { 8. évfolyam }\end{array}$ & $\begin{array}{l}\text { Q-próba/ } \\
\chi^{2} \text {-próba } \\
\text { (p-érték) }\end{array}$ & $\begin{array}{l}\text { 1. vizsgálat } \\
\text { (T1) } \\
\text { 9. évfolyam }\end{array}$ & $\begin{array}{l}\text { 2. vizsgálat } \\
\text { (T2) } \\
\text { 10. évfolyam }\end{array}$ & $\begin{array}{l}\text { 3. vizsgálat } \\
\text { (T3) } \\
\text { 11. évfolyam }\end{array}$ & $\begin{array}{l}\text { Q-próba/ } \\
\chi^{2} \text {-próba } \\
\text { (p-érték) }\end{array}$ \\
\hline Nem (lány, \%) & 48,6 & 48,6 & 48,6 & n. a. & 58,4 & 58,4 & 58,4 & n. a. \\
\hline $\begin{array}{l}\text { Átlagéletkor években } \\
\text { (SD) }\end{array}$ & $\begin{array}{l}12,00 \\
(0,57)\end{array}$ & $\begin{array}{l}12,99 \\
(0,61)\end{array}$ & $\begin{array}{l}14,08 \\
(0,57)\end{array}$ & n. a. & $\begin{array}{l}15,01 \\
(0,59)\end{array}$ & $\begin{array}{l}16,03 \\
(0,58)\end{array}$ & $\begin{array}{l}17,09 \\
(0,57)\end{array}$ & n. a. \\
\hline $\begin{array}{l}\text { Iskola telephelye } \\
\text { (föváros, \%) }\end{array}$ & 68,7 & 68,7 & 68,7 & n. a. & 51,2 & 51,2 & 51,2 & n. a. \\
\hline $\begin{array}{l}\text { Tanulmányi eredmény } \\
\text { átlaga }(\geq 3,51 ; \%)\end{array}$ & 83,3 & 78,0 & 76,3 & $\begin{array}{l}14,8 \\
(0,001)\end{array}$ & 66,8 & 53,5 & 54,4 & $\begin{array}{l}64,2 \\
(<0,001)\end{array}$ \\
\hline $\begin{array}{l}\text { Heti zsebpénz }(\geq 1001 \\
\text { forint, } \%)\end{array}$ & 21,6 & 28,4 & 36,4 & $\begin{array}{l}43,0 \\
(<0,001)\end{array}$ & 42,7 & 45,0 & 46,9 & $\begin{array}{l}5,6 \\
(0,061)\end{array}$ \\
\hline \multicolumn{9}{|l|}{ Családszerkezet (\%) } \\
\hline Intakt család & 70,8 & 67,7 & 67,2 & & 68,3 & 65,9 & 64,2 & \\
\hline Újrastrukturált család & 10,4 & 10,9 & 12,4 & \multirow{2}{*}{$\begin{array}{l}9,3 \\
(0,010)\end{array}$} & 9,8 & 10,7 & 11,7 & \multirow{2}{*}{$\begin{array}{l}21,7 \\
(<0,001)\end{array}$} \\
\hline $\begin{array}{l}\text { Egyszülős/egyéb } \\
\text { család }\end{array}$ & 18,8 & 21,4 & 20,3 & & 21,9 & 23,4 & 24,2 & \\
\hline $\begin{array}{l}\text { Egyik/mindkét szülő } \\
\text { dohányzik }(\%)\end{array}$ & 43,2 & 41,5 & 41,0 & $\begin{array}{l}3,0 \\
(0,225)\end{array}$ & 47,2 & 46,9 & 44,8 & $\begin{array}{l}3,2 \\
(0,206)\end{array}$ \\
\hline $\begin{array}{l}\text { Cigarettázó legjobb } \\
\text { barátok számának átlaga } \\
(\mathrm{SD})\end{array}$ & $\begin{array}{l}0,64 \\
(1,34)\end{array}$ & $\begin{array}{l}1,14 \\
(1,80)\end{array}$ & $\begin{array}{l}1,52 \\
(1,78)\end{array}$ & $\begin{array}{l}97,0 \\
(<0,001)\end{array}$ & $\begin{array}{l}2,66 \\
(1,86)\end{array}$ & $\begin{array}{l}2,81 \\
(1,82)\end{array}$ & $\begin{array}{l}2,75 \\
(1,78)\end{array}$ & $\begin{array}{l}6,5 \\
(0,040)\end{array}$ \\
\hline
\end{tabular}

Megjegyzés: Q-próba: Cochran-féle Q-próba; $\chi^{2}$-próba: Friedman-próba; n. a.: nem alkalmazható. 
rendszerességgel cigarettázó legjobb barátok számának átlaga főleg a fiatalabb, de az idősebb csoportban is egyaránt szignifikánsan növekedett.

\section{A dohányzó-magatartás alakulása a két kohorszban}

A cigarettakipróbálás és az aktuális dohányzás alakulását a fiatalabb és idősebb kohorsz mintáiban, valamint ezeken belül nemek szerinti bontásban, kereszttábla-elemzésekkel és Cochran-féle Q-próbával vizsgáltuk (3. táblázat). A cigarettát valaha kipróbálók prevalenciája a kiindulástól a T3 időpontra szignifikánsan növekedett mind a fiatalabb, mind az idősebb kohorszban. Nemek szerint egyik kohorszban sem különbözött lényegesen a kipróbálás előfordulási gyakorisága az egyes mérési pontokon, habár a fiatalabbaknál inkább a fiúkra, az idősebbeknél inkább a lányokra volt jellemzőbb. Az elmúlt havi dohányzás prevalenciája T3 idejére a kiinduláshoz viszonyítva 9,7\%-kal emelkedett az általános iskolások, illetve 12,0\%-kal a középiskolások körében. Fiúk és lányok között az aktuális dohányzásban sem lehetett szignifikáns különbséget kimutatni, ám említésre méltó, hogy mindkét kohorszban a lányok körében a gyakoriság fokozottabban növekedett a fiúkhoz képest. A napi rendszerességű dohányzás gyakorisága a fiatalabb kohorszban több mint négyszeresére, az idősebb csoportban pedig közel kétszeresére növekedett. Nagyobb mértékü emelkedést ebben az esetben is a lányoknál lehetett megfigyelni. Nemi különbség egyik mérési ponton sem jelentkezett.

\section{Dohányzói életutak alakulása és kapcsolatuk szociodemográfiai és társas befolyásoló tényezőkkel}

Dohányzói életutak tekintetében a minta 67,5\%-a őrizte meg nem dohányzó magatartását. Ugyanakkor a résztvevók 11,3\%-a mindhárom fázisban dohányzott, míg 14,3\%-a rászokott a dohányzásra, továbbá 3,3\%-a leszokott, illetve 3,7\%-a kísérletező maradt.

A dohányzói életutak és a kiindulási (Tl) vizsgálat alapján egyes szociodemográfiai jellemzők közötti kapcsolatot a 4. táblázat mutatja be. A fiúk és a lányok hasonló arányban voltak végig dohányzók, azonban a három év alatt több lány szokott rá a cigarettára, mint fiú, ugyanakkor kétszer annyi fiú tartozott a kísérletezők közé a lányokhoz képest. A két életkori kohorszban a dohányzói életutak előfordulási gyakorisága szignifikánsan különbözött egymástól, ugyanis a mindvégig dohányzók, a kísérletezők, a rászokók és a leszokók aránya egyaránt magasabb volt az idősebbek, mint a fiatalabbak között. Az egyes kohorszok dohányzói életútjait nemen-

3. táblázat | A dohányzó-magatartás alakulása a kutatás három éve alatt a fiatalabb $(n=467)$ és az idősebb $(n=625)$ kohorszban

\begin{tabular}{|c|c|c|c|c|c|c|c|}
\hline \multirow[t]{2}{*}{ Változók } & \multicolumn{2}{|l|}{$\mathrm{Tl}$} & \multicolumn{2}{|l|}{$\mathrm{T} 2$} & \multicolumn{2}{|l|}{$\mathrm{T} 3$} & \multirow{2}{*}{$\begin{array}{l}\mathrm{T} 1-\mathrm{T} 2-\mathrm{T} 3 \\
\mathrm{Q}_{(2)} \\
\text { (p-érték) }\end{array}$} \\
\hline & $\mathrm{n}(\%)$ & $\begin{array}{l}\chi^{2}(1) \\
(p \text {-érték) }\end{array}$ & n (\%) & $\begin{array}{l}\chi_{(1)}^{2} \\
(\mathrm{p} \text {-érték) }\end{array}$ & $\mathrm{n}(\%)$ & $\begin{array}{l}\chi^{2}(1) \\
\text { (p-érték) }\end{array}$ & \\
\hline \multicolumn{8}{|l|}{ Fiatalabb kohorsz } \\
\hline Kipróbálta a cigarettát & $92(19,7)$ & - & $146(31,3)$ & - & $194(41,5)$ & - & $153,18(<0,001)$ \\
\hline Fiú & $55(22,9)$ & \multirow{2}{*}{$\begin{array}{l}3,23 \\
(0,072)\end{array}$} & $78(32,5)$ & \multirow{2}{*}{$\begin{array}{l}0,35 \\
(0,553)\end{array}$} & $99(41,3)$ & \multirow{2}{*}{$\begin{array}{l}0,02 \\
(0,895)\end{array}$} & \\
\hline Lány & $37(16,3)$ & & $68(30,0)$ & & $95(41,9)$ & & \\
\hline Aktuálisan cigarettázott & $17(3,6)$ & - & $30(6,4)$ & - & $62(13,3)$ & - & $48,76(<0,001)$ \\
\hline Fiú & $9(3,8)$ & \multirow{2}{*}{$\begin{array}{l}0,02 \\
(0,896)\end{array}$} & $14(5,8)$ & \multirow{2}{*}{$\begin{array}{l}0,29 \\
(0,592)\end{array}$} & $26(10,8)$ & \multirow{2}{*}{$\begin{array}{l}2,56 \\
(0,110)\end{array}$} & \\
\hline Lány & $8(3,5)$ & & $16(7,0)$ & & $36(15,9)$ & & \\
\hline Naponta cigarettázott & $5(1,1)$ & - & $7(1,5)$ & - & $22(4,7)$ & - & $18,50(<0,001)$ \\
\hline Fiú & $2(0,8)$ & \multirow{2}{*}{$\begin{array}{l}0,26 \\
(0,608)\end{array}$} & $3(1,3)$ & \multirow{2}{*}{$\begin{array}{l}0,21 \\
(0,649)\end{array}$} & $9(3,8)$ & \multirow{2}{*}{$\begin{array}{l}1,02 \\
(0,314)\end{array}$} & \\
\hline Lány & $3(1,3)$ & & $4(1,8)$ & & $13(5,7)$ & & \\
\hline \multicolumn{8}{|l|}{ Idösebb kohorsz } \\
\hline Kipróbálta a cigarettát & $353(56,5)$ & - & $417(66,7)$ & - & $454(72,6)$ & - & $155,11(<0,001)$ \\
\hline Fiú & $138(53,1)$ & \multirow{2}{*}{$\begin{array}{l}2,10 \\
(0,148)\end{array}$} & $168(64,6)$ & \multirow{2}{*}{$\begin{array}{l}0,89 \\
(0,346)\end{array}$} & $185(71,2)$ & \multirow{2}{*}{$\begin{array}{l}0,50 \\
(0,482)\end{array}$} & \\
\hline Lány & $215(58,9)$ & & $249(68,9)$ & & $269(73,7)$ & & \\
\hline Aktuálisan cigarettázott & $155(24,8)$ & - & $205(32,8)$ & - & $230(36,8)$ & - & $52,71(<0,001)$ \\
\hline Fiú & $64(24,6)$ & \multirow{2}{*}{$\begin{array}{l}0,01 \\
(0,928)\end{array}$} & $92(35,4)$ & \multirow{2}{*}{$\begin{array}{l}1,35 \\
(0,245)\end{array}$} & $89(34,2)$ & \multirow{2}{*}{$\begin{array}{l}1,26 \\
(0,261)\end{array}$} & \\
\hline Lány & $91(24,9)$ & & $113(31,0)$ & & $141(38,6)$ & & \\
\hline Naponta cigarettázott & $53(8,5)$ & - & $84(13,4)$ & - & $91(14,6)$ & - & $30,68(<0,001)$ \\
\hline Fiú & $21(8,1)$ & \multirow{2}{*}{$\begin{array}{l}0,09 \\
(0,760)\end{array}$} & $36(13,8)$ & \multirow{2}{*}{$\begin{array}{l}0,06 \\
(0,802)\end{array}$} & $36(13,9)$ & \multirow{2}{*}{$\begin{array}{l}0,17 \\
(0,684)\end{array}$} & \\
\hline Lány & $32(8,8)$ & & $48(13,2)$ & & $55(15,1)$ & & \\
\hline
\end{tabular}

Megjegyzés: $\chi^{2}$ : Pearson-féle $\chi^{2}$-próba; Q: Cochran-féle Q-próba. 


\begin{tabular}{|c|c|c|c|c|c|c|c|}
\hline \multirow[t]{2}{*}{ Változók (kiinduláskor - T1) } & \multicolumn{5}{|c|}{ Dohányzói életutak } & \multirow[t]{2}{*}{ Statisztikai próba } & \multirow[t]{2}{*}{ p-érték } \\
\hline & $\begin{array}{l}\text { Nem dohányzó } \\
\mathrm{n}=737\end{array}$ & $\begin{array}{l}\text { Kísérletező } \\
\mathrm{n}=40\end{array}$ & $\begin{array}{l}\text { Rászokott } \\
\mathrm{n}=156\end{array}$ & $\begin{array}{l}\text { Leszokott } \\
\mathrm{n}=36\end{array}$ & $\begin{array}{l}\text { Dohányzó } \\
\mathrm{n}=123\end{array}$ & & \\
\hline \multicolumn{8}{|l|}{ Szociodemográfiai változók } \\
\hline \multicolumn{8}{|l|}{ Nem $(\%)$} \\
\hline Fiú $(\mathrm{n}=500)$ & 70,4 & 5,0 & 11,2 & 2,8 & 10,6 & \multirow{2}{*}{$\begin{array}{l}\chi_{(4)}^{2}=12,86 ; \\
\text { Cramer V }=0,11\end{array}$} & \multirow[t]{2}{*}{0,012} \\
\hline Lány $(\mathrm{n}=592)$ & 65,0 & 2,5 & 16,9 & 3,7 & 11,8 & & \\
\hline \multicolumn{8}{|l|}{ Életkori kohorsz (\%) } \\
\hline Fiatalabb $(n=467)$ & 84,2 & 1,5 & 11,1 & 1,5 & 1,7 & \multirow{2}{*}{$\begin{array}{l}\chi_{(4)}^{2}=123,75 ; \\
\text { Cramer } V=0,34\end{array}$} & \multirow[t]{2}{*}{$<0,001$} \\
\hline Idősebb $(\mathrm{n}=625)$ & 55,0 & 5,3 & 16,6 & 4,6 & 18,4 & & \\
\hline \multicolumn{8}{|l|}{ Családszerkezet (\%) } \\
\hline Intakt $(\mathrm{n}=753)$ & 71,8 & 3,3 & 12,2 & 3,2 & 9,4 & \multirow{3}{*}{$\begin{array}{l}\chi_{(4)}^{2}=34,08 \\
\text { Cramer V }=0,13\end{array}$} & \multirow[t]{3}{*}{$<0,001$} \\
\hline Újrastrukturált ( $\mathrm{n}=109)$ & 52,3 & 9,2 & 21,1 & 3,7 & 13,8 & & \\
\hline Egyszülős/egyéb (n = 223) & 60,1 & 2,2 & 17,5 & 3,6 & 16,6 & & \\
\hline $\begin{array}{l}\text { Heti zsebpénzkódok átlaga } \\
\text { (átlag 95\%-os konfidencia } \\
\text { intervalluma) }\end{array}$ & $\begin{array}{l}2,8 \\
(2,7-2,9)\end{array}$ & $\begin{array}{l}3,7 \\
(2,9-4,4)\end{array}$ & $\begin{array}{l}3,2 \\
(2,9-3,5)\end{array}$ & $\begin{array}{l}3,0 \\
(2,4-3,6)\end{array}$ & $\begin{array}{l}3,7 \\
(3,3-4,1)\end{array}$ & $\mathrm{H}_{(4)}=30,59$ & $<0,001$ \\
\hline $\begin{array}{l}\text { Tanulmányieredmény-kódok } \\
\text { átlaga (átlag 95\%-os } \\
\text { konfidencia intervalluma) }\end{array}$ & $\begin{array}{l}4,6 \\
(4,5-4,7)\end{array}$ & $\begin{array}{l}3,9 \\
(3,4-4,3)\end{array}$ & $\begin{array}{l}4,1 \\
(3,8-4,3)\end{array}$ & $\begin{array}{l}3,7 \\
(3,2-4,1)\end{array}$ & $\begin{array}{l}3,4 \\
(3,1-3,6)\end{array}$ & $\mathrm{H}_{(4)}=103,70$ & $<0,001$ \\
\hline \multicolumn{8}{|l|}{ Társas hatások } \\
\hline \multicolumn{8}{|l|}{ Szülői dohányzás (\%) } \\
\hline $\begin{array}{l}\text { Egyik szülő sem dohányzik } \\
(\mathrm{n}=585)\end{array}$ & 74,0 & 3,2 & 13,7 & 2,6 & 6,5 & \multirow[t]{2}{*}{$\begin{array}{l}\chi_{(4)}^{2}=36,56 ; \\
\text { Cramer V =0,19 }\end{array}$} & \multirow[t]{2}{*}{$<0,001$} \\
\hline $\begin{array}{l}\text { Egyik/mindkét szülő } \\
\text { dohányzik }(\mathrm{n}=488)\end{array}$ & 59,6 & 4,3 & 15,2 & 4,1 & 16,8 & & \\
\hline $\begin{array}{l}\text { Cigarettázó legjobb barátok } \\
\text { számának átlaga (átlag 95\%-os } \\
\text { konfidencia intervalluma) }\end{array}$ & $\begin{array}{l}1,2 \\
(1,1-1,3)\end{array}$ & $\begin{array}{l}3,0 \\
(2,4-3,6)\end{array}$ & $\begin{array}{l}2,2 \\
(1,9-2,6)\end{array}$ & $\begin{array}{l}3,4 \\
(2,9-4,0)\end{array}$ & $\begin{array}{l}4,0 \\
(3,7-4,2)\end{array}$ & $\mathrm{H}_{(4)}=258,19$ & $<0,001$ \\
\hline
\end{tabular}

Megjegyzés: Nem dohányzók: Egyik mérési időpontban sem dohányoztak az elmúlt 30 napban. Kísérletezők: A vizsgálat során váltakozva rászoktak vagy leszoktak, és fordítva. Rászokók: T1 méréskor nem dohányoztak, de T2 vagy T3 időpontban már igen. Leszokók: T1 időpontban dohányoztak, majd T2, illetve T3 méréskor már nem. Dohányzók: mindhárom mérési időpontban dohányoztak.

Az értékek/arányok soronként adnak ki 100\%-ot. $\chi^{2}$ : Pearson-féle $\chi^{2}$-próba; H: Kruskal-Wallis-próba.

kénti bontásban vizsgálva, a fiatalabbak körében jelentéktelen volt a különbség $\left(\chi_{(4)}^{2}=6,04 ; \mathrm{p}=0,196\right)$, de a három év során több lány $(14,1 \%)$, mint fiú $(8,3 \%)$ szokott rá a cigarettára. Középiskolásoknál ugyanakkor számottevő nemi különbségek adódtak $\left(\chi_{(4)}^{2}=10,82 ; \mathrm{p}=\right.$ $0,029)$. Itt több fiú maradt mindvégig nem dohányzó $(55,4 \%)$, mint lány $(51,9 \%)$, ám a kísérletezés inkább az előbbieket jellemezte $(8,5 \%)$ a lányokkal ellentétben $(3,0 \%)$. Lányok körében viszont ezúttal is nagyobb mértékű volt a rászokás $(18,6 \%)$, mint a fiúknál (13,8\%). Családszerkezet tekintetében a kiinduláskor is újrastrukturált családban élő diákok szoktak rá a cigarettára, illetve kísérleteztek vele a legnagyobb arányban, viszont az egyszülős vagy egyéb szerkezetű családban élők tartoztak legtöbben a mindvégig dohányzó csoportba. A heti zsebpénz összege és a dohányzói életutak között szignifikáns összefüggést találtunk. A dohányzói életutak páronkénti összehasonlítása során a nagy elemszámra való tekintettel a korrigált szignifikanciaértékeket vettük figyelembe. Ennek megfelelően a mindvégig dohányzóknak jelentősen több zsebpénze volt kiinduláskor, mint a nem dohányzóknak $(\mathrm{p}<0,001)$. A tanulmányi eredmény és az egyes dohányzói csoportokba tartozás között szintén szignifikáns kapcsolatot találtunk. Páronkénti összehasonlításban a mindvégig nem dohányzóknak a kiinduláskor jelentősen jobb tanulmányi teljesítménye volt, szemben a mindvégig dohányzókkal $(\mathrm{p}<0,001)$, a rászokókkal $(\mathrm{p}<0,001)$, a leszokókkal $(\mathrm{p}=0,001)$ és a kísérletezőkkel $(\mathrm{p}=0,009)$. Emellett a kutatás indulásakor a dohányzókhoz képest a rászokók jelentősen jobb tanulmányi eredményről ( $\mathrm{p}=0,001)$ számoltak be .

Az egyes dohányzói életutakban a társas befolyásoló tényezők közül a szülők és a legjobb barátok dohányzó magatartásának szerepét vizsgáltuk. Azok a fiatalok, akiknek egyik szülője sem dohányzott, jelentősen nagyobb arányban maradtak nem dohányzók, míg ha egyik 
vagy mindkét szülőjük dohányzott, közel háromszor annyian dohányoztak mindvégig, mint az elóbbi csoportban. A dohányzói életutak és az első adatfelvétel során felmért cigarettázó legjobb barátok száma közötti kapcsolatot vizsgálva a mindvégig dohányzó résztvevőknek kiinduláskor jelentősen több, legalább heti rendszerességgel cigarettázó barátja volt, mint a mindvégig nem dohányzóknak. Az utóelemzés páronkénti összehasonlítása során a nem dohányzó tanulóknak kiinduláskor szignifikánsan kevesebb, legalább heti rendszerességgel cigarettázó legjobb barátja volt, mint az összes többi dohányzói csoportba tartozóknak $(\mathrm{p}<0,001$, mindegyik páronkénti összehasonlítás esetében). Emellett a rászokóknak a dohányzókhoz $(\mathrm{p}<0,001)$, illetve a leszokókhoz képest $(\mathrm{p}=0,014)$ is kevesebb dohányzó barátja volt.

\section{Megbeszélés}

Longitudinális kutatásunk lehetővé tette a dohányzómagatartás változásának nyomon követését ugyanazon diákok körében. Az adatok világosan jelzik, hogy az általános iskolás kohorszban a rendszeres cigarettahasználat évről évre szinte megduplázódott. A nyolcadikosokat ugyan nem követtük, ám a kilencedikesek prevalenciaadata alapján feltételezhető, hogy a duplázódás még a középiskoláskorba lépés évében is fennáll, ezt követően viszont mérséklődik a növekedés. Tekintettel a minta szelektív jellegére, az sem hagyható figyelmen kívül, hogy a jobb tanulmányi eredményű, elsősorban fóvárosi, kevesebb zsebpénzzel rendelkező, kiinduláskor kedvezőbb családszerkezetben élő tanulók körében is fokozottabban kell figyelni a dohányzás elsődleges megelőzésére.

Követéses vizsgálatok hiányában mindeddig ismeretlen volt, hogy miként alakul a cigarettára rászokás, illetve leszokás folyamata magyar serdülők körében. Mintánkban három év alatt a diákok 14,3\%-a szokott rá a cigarettára, a leszokás aránya viszont csak 3,3\% volt. Adataink közelítik az Amerikai Egyesült Államokban végzett hasonló időtartamú kutatások eredményeit. Stice és Martinez három éven keresztül, három adatfelvételi fázisban vizsgálta 11-15 éves nagyvárosi iskolás lányok körében a dohányzói életutak alakulását, és a rászokás mértékét 11,1\%-nak, a leszokást 7,5\%-nak találták [15]. Egy másik tanulmányban telefonos kérdezéssel három éven át félévenként követtek 12-16 éves serdülőket. Két csoportot azonosítottak az újonnan rászokók körében, az úgynevezett kipróbálókat (17\%) és az alkalmi dohányzókat (10\%). Utóbbiak a vizsgálat végére egyre többször gyújtottak rá, de ritkábban, mint havi rendszerességgel. Ennek a mintának 4\%-a úgynevezett leszokásban lévő csoport volt, akik korábban rendszeresen, de a vizsgálat végére már csak ritkábban, mint havonta cigarettáztak [11]. Egy másik kutatásban hat év alatt, három adatfelvétel során 9-11. évfolyamos fiatalokat követtek, akiknek 6,8\%-a vált egyáltalán nem dohányzóból napi rendsze- rességgel cigarettázóvá a második utánkövetés idejére, ugyanakkor 2,9\%-uk jelentősen csökkentette a cigarettafogyasztását [25].

A cigarettára rászokó nagyvárosi serdülők demográfiai, egyéni és társas jellemzőit összegezve megállapítható, hogy a kutatás végére elsősorban az idősebb lányok és az újrastrukturált családban élők váltak legalább havi rendszerességgel dohányzóvá. Tanulmányi eredményük kezdetben inkább jónak számított, és túlzottan sok cigarettázó legjobb barátjuk sem volt, a többi dohányzói csoporttal szemben. A minta kis hányada nem kötelezte el magát sem a rászokás, sem a leszokás mellett, ezért soroltuk őket a cigarettázással kísérletezők közé. Leginkább idősebb fiúk voltak, akik a kutatás kezdetén jellemzően ugyancsak újrastrukturált családban éltek, kissé több zsebpénzzel rendelkeztek és viszonylag jó tanulmányi átlagról számoltak be, ugyanakkor több cigarettázó barátjuk volt, mint a rászokóknak. A mindvégig dohányzó csoport tagjai elsősorban az idősebb kohorszba tartoztak, a vizsgálat első fázisában túlnyomórészt egyszülős vagy egyéb szerkezetû családban éltek, több zsebpénzzel rendelkeztek és az összes többi csoporthoz viszonyítva a leggyengébb volt a tanulmányi eredményük. Esetükben jellemzőbb volt a szülők dohányzása, valamint legjobb barátaik is inkább cigarettáztak. Jobbára a középiskolások szoktak le a cigarettáról, kiinduláskor pedig azt jelezték, hogy legjobb barátaik többsége, valamint szüleik is dohányoznak, tanulmányi átlaguk alapján pedig nem a jobbak közé tartoztak.

Bár kutatásunk lehetőséget adott a magyar serdülők dohányzói magatartásának újszerü, longitudinális vizsgálatára, néhány korlátját mégis szükséges megemlítenünk. A mintavétel nagyvárosi serdülők körében történt, így eredményeink más településtípusokra nem általánosíthatók. Longitudinális kutatásunk az iskolarendszeren belül maradókra korlátozódott, így eredményeinkból nem lehet következtetéseket levonni a rendszerból kiesettekre. A vizsgálat prospektív természetéből adódóan a kiindulási minta fele lemorzsolódott, ezért a három fázisban végigkövetett serdülők azok közül kerültek ki, akiknek jobb volt a tanulmányi eredménye, elsősorban fövárosi iskolában tanultak, kevesebb zsebpénzzel rendelkeztek, kedvezőbb családszerkezetben éltek és kevésbé próbálkoztak a cigarettázással, illetve rendszeresen nem dohányoztak. Önbeszámolós módszerünk miatt a dohányzási szokásokat illetően nem tekinthetünk el a válaszok többé-kevésbé torzító jellegétől. Ez a módszer általában alulbecsüli a dohányzás tényleges prevalenciáját, így kedvezőbb irányban tér el a biokémiai mérésekkel igazolt eredményektől. Figyelembe véve azonban a dohányzás biokémiai validálásának jelentős költség- és egyéb erőforrásigényét, nagyobb mintákon elfogadható az önbeszámolós módszer, a költségtakarékosság és az egyszerübb kivitelezhetőség érdekében [26].

Tanulmányunkban magyar serdülők körében prospektív módszerrel azonosítottuk a dohányzással kapcsolatos magatartás időbeli alakulását és az ezt befolyásoló ténye- 
zőket. Eredményeink rávilágítanak arra, hogy a különböző dohányzói magatartást mutató csoportokban más és más kockázati tényezők kerülnek előtérbe, amelyek ismerete nélkül nem lehet célzott prevenciós programokat tervezni. Mindezek alapján az eltérő dohányzási fázisban lévő tizenéveseket értelmetlen összevontan kezelni a prevenciós beavatkozások kapcsán, ugyanis a differenciálatlanul közvetített üzenetek és készségek nagy valószínúséggel hatástalanok maradnak. Emellett a beavatkozások tartalmát nemcsak korcsoportonként, hanem dohányzói csoportok szerint is javasolt differenciálni [27]. A kipróbálás és progresszió szempontjából kritikus életkort megelőzően mindenképpen szükség volna az adott korosztály életkori sajátosságaihoz igazított, általános megközelítésű prevencióra. A kritikus életkortól kezdve a szekunder prevenciót, azaz a dohányzásprogresszió megelőzését és a leszokás elősegítését is javasolt alkalmazni $[13,28]$. Megfontolandó volna, hogy a prevenciós programok egy kortárs- és egy szülői komponenst is tartalmazzanak. A kortárskomponensnek a nem dohányzó normák elfogadására és ezek megerősítésére kellene irányulnia, míg a szülőii komponens a szülő-gyermek kapcsolat javításának lehetőségeit, a monitorozás mikéntjét, a dohányzással kapcsolatos szabályállításokat és szükség esetén a szülő(k) leszokásban való támogatását tartalmazhatná. Javasolt az iskolaalapú megelőző programok kiegészítése családalapú intervenciókkal, amelyek együttesen különösen hatékonnyá válhatnak a cigarettakipróbálás és a rászokás megelőzésében [29-31]. Öszszegzésként a nemzetközi dohányzásprevenciós javaslatokat alátámasztó eredményeink alapján javasoljuk a hazai megelőző programok újragondolását.

Anyagi támogatás: A tanulmány elkészítését az amerikai egyesült államokbeli Fogarty International Centre, a National Cancer Institute és a National Institutes on Drug Abuse (National Institutes of Health) támogatása (1 R01 TW007927-01) tette lehetővé.

Szerzôi munkamegosztás: P. M.: A kutatási módszertan kidolgozása, a vizsgálat lefolytatása, szakirodalom-kutatás, statisztikai elemzések, a kézirat szövegezése és javítása. Cz. E.: Statisztikai elemzések, a kézirat véleményezése. B. P.: A kutatási módszertan kidolgozása, a kézirat véleményezése. U. R.: A kutatási módszertan kidolgozása, a kézirat véleményezése. A cikk végleges változatát valamennyi szerző elolvasta és jóváhagyta.

Érdekeltségek: A szerzőknek nincsenek érdekeltségeik.

\section{Köszönetnyilvánítás}

A szerzők köszönetüket fejezik ki Huszár Ágnesnek, Mizsei Enikőnek és további kollégáiknak az adatgyújtésben és adatbevitelben nyújtott munkájukért.

\section{Irodalom}

[1] U.S. Department of Health and Human Services: Preventing tobacco use among youth and young adults: a report of the Surgeon General. Department of Health and Human Services, Centers for Disease Control and Prevention, National Center for Chronic Disease Prevention and Health Promotion, Office on Smoking and Health, Atlanta, GA, U.S. 2012. http://www. ncbi.nlm.nih.gov/books/NBK99237/

[2] Park, S., June, K. J.: The importance of smoking definitions for the study of adolescent smoking behavior. Taehan Kanho Hakhoe Chi, 2006, 36(4), 612-620.

[3] Leventhal, H., Cleary, P. D.: The smoking problem: a review of the research and theory in behavioral risk modification. Psychol. Bull., 1980, 88(2), 370-405.

[4] Flay, B. R.: Youth tobacco use: Risks, patterns, and control. In: Orleans, C. T., Slade, J. (eds.): Nicotine addiction: Principles and management. Oxford University Press, New York, 1993, 365384.

[5] Mayhew, K. P., Flay, B. R., Mott, J. A.: Stages in the development of adolescent smoking. Drug Alcohol Depend., 2000, 59(Suppl. 1), S61-S81.

[6] Prokborov, A. V., de Moor, C. A., Hudmon, K. S., et al.: Predicting initiation of smoking in adolescents: evidence for integrating the stages of change and susceptibility to smoking constructs. Addict. Behav., 2002, 27(5), 697-712.

[7] Prochaska, J. O., DiClemente, C. C.: Stages and processes of selfchange of smoking: toward an integrative model of change. J. Consult. Clin. Psychol., 1983, 51(3), 390-395.

[8] Urbán, R.: Health psychology of health impairing behaviors. In: Kállai, J., Varga, J., Oláh, A. (eds.): Health psychology in practice. $[\mathrm{Az}$ egészségkárosító viselkedések klinikai egészségpszichológiai megközelítése. In: Kállai, J., Varga, J., Oláh, A. (szerk.): Egészségpszichológia a gyakorlatban.] Medicina Könyvkiadó, Budapest, 2014, 279-303. [Hungarian]

[9] Pierce, J. P., Choi, W. S., Gilpin, E. A., et al.: Validation of susceptibility as a predictor of which adolescents take up smoking in the United States. Health Psychol., 1996, 15(5), 355-361.

[10] Colder, C. R., Mehta, P., Balanda, K., et al.: Identifying trajectories of adolescent smoking: an application of latent growth mixture modeling. Health Psychol., 2001, 20(2), 127-135.

[11] Bernat, D. H., Erickson, D. J., Widome, R., et al.: Adolescent smoking trajectories: results from a population-based cohort study. J. Adolesc. Health, 2008, 43(4), 334-340.

[12] White, H. R., Pandina, R. J., Chen, P. H.: Developmental trajectories of cigarette use from early adolescence into young adulthood. Drug Alcohol Depend., 2002, 65(2), 167-178.

[13] Audrain-McGovern, J., Rodriguez, D., Tercyak, K. P., et al.: Identifying and characterizing adolescent smoking trajectories. Cancer Epidemiol. Biomarkers Prev., 2004, 13(12), 2023-2034.

[14] Karp, I., O'Loughlin, J., Paradis, G., et al.: Smoking trajectories of adolescent novice smokers in a longitudinal study of tobacco use. Ann. Epidemiol., 2005, 15(6), 445-452.

[15] Stice, E., Martinez, E. E.: Cigarette smoking prospectively predicts retarded physical growth among female adolescents. J. Adolesc. Health, 2005, 37(5), 363-370.

[16] Xie, B., Palmer, P., Li, Y., et al.: Developmental trajectories of cigarette use and associations with multilayered risk factors among Chinese adolescents. Nicotine Tob. Res., 2013, 15(10), 1673-1681.

[17] Fuemmeler, B., Lee, C. T., Ranby, K. W., et al.: Individual- and community-level correlates of cigarette-smoking trajectories from age 13 to 32 in a U.S. population-based sample. Drug Alcohol Depend., 2013, 132(1-2), 301-308.

[18] Arnold, P.: Tobacco use. In: Németh, Á., Arnold, P., Kökönyei, Gy. (eds.): Health Behaviour in School-aged Children (HBSC): 
A WHO-collaborative Cross-National Study, National Report, 2014. [Dohányzási szokások. In: Egészség és egészségmagatartás iskoláskorban, 2014. Az iskoláskorú gyermekek egészségmagatartása elnevezésű, az Egészségügyi Világszervezettel együttmúködésben megvalósuló nemzetközi kutatás 2014. évi felmérésérôl készült nemzeti jelentés.] Nemzeti Egészségfejlesztési Intézet, Budapest, 2016, 47-57. [Hungarian]

[19] Balku, E., Demjén, T., Kimmel, Zs., et al.: Global Youth Tobacco Survey, Word Health Organization, WHO GYTS 2013. [Nemzetközi Ifjúsági Dohányzásfelmérés. Egészségügyi Világszervezet. Összefoglaló tanulmány 2013.] Dohányzás Fókuszpont, Országos Egészségfejlesztési Intézet, Budapest, 2013. http://www.fokuszpont.dohanyzasvisszaszoritasa.hu/sites/default/files/01_GYTS_2013_osszefoglalo_tanulmany.pdf [Hungarian]

[20] Elekes, Zs.: ESPAD 2011 - Fifth wave of the European School Survey Project on Alcohol and other Drugs. [ESPAD 2011 (Európai iskolavizsgálat a fiatalok alkohol- és egyéb drogfogyasztási szokásairól) - ötödik hullámának magyarországi adatfelvétele.] Budapesti Corvinus Egyetem, Szociológia és Társadalompolitika Intézet, 2012. [Hungarian]

[21] Urbán, R.: Cognitive predictors of adolescent smoking in a longitudinal study. DSc-thesis of the Hungarian Academy of Sciences, 2016. [A serdülőkori dohányzás kognitív prediktorainak vizsgálata longitudinális elrendezésben.] Akadémiai doktori értekezés tézisei, 2016. http://real-d.mtak.hu/879/ [Hungarian]

[22] California Department of Public Health: California Student Tobacco Survey (CSTS) 2007-2008. https://www.cdph.ca.gov/ programs/tobacco/Pages/CTCPEvaluationResources.aspx

[23] International Agency for Research on Cancer (IARC): Measuring tobacco use behaviours. In: IARC handbook of cancer prevention, Volume 12: Methods for evaluating tobacco control policies. International Agency for Research on Cancer, Lyon, 2008, 75-105. http://publications.iarc.fr/Book-And-Report-Series/
Iarc-Handbooks-Of-Cancer-Prevention/Methods-For-Evaluating-Tobacco-Control-Policies-2008

[24] Vargha, A., Torma, B., Bergman, L. R.: ROPstat: A general statistical package useful for conducting person-oriented analyses. J. Person-Oriented Res., 2015, 1(1-2), 87-98.

[25] Pollard, M. S., Tucker, J. S., Green, H. D., et al.: Friendship networks and trajectories of adolescent tobacco use. Addict. Behav., $2010,35(7), 678-685$

[26] Connor Gorber, S., Schofield-Hurwitz, S., Hardt, J., et al.: The accuracy of self-reported smoking: a systematic review of the relationship between self-reported and cotinine-assessed smoking status. Nicotine Tob. Res., 2009, 11(1), 12-24.

[27] Abroms, L., Simons-Morton, B., Haynie, D. L., et al.: Psychosocial predictors of smoking trajectories during middle and high school. Addiction, 2005, 100(6), 852-861.

[28] Riggs, N. R., Chou, C. P., Li, C., et al.: Adolescent to emerging adulthood smoking trajectories: When do smoking trajectories diverge, and do they predict early adulthood nicotine dependence? Nicotine Tob. Res., 2007, 9(11), 1147-1154.

[29] Mababee-Gittens, E. M., Xiao, Y., Gordon, J. S., et al.: The dynamic role of parental influences in preventing adolescent smoking initiation. Addict. Behav., 2013, 38(4), 1905-1911.

[30] Vitória, P. D., Salgueiro, M. F., Silva, S. A., et al.: The impact of social influence on adolescent intention to smoke: combining types and referents of influence. Br. J. Health Psychol., 2009, 14(4), 681-699.

[31] Thomas, R. E., Baker, P. R., Thomas, B. C., et al.: Family-based programmes for preventing smoking by children and adolescents. Cochrane Database Syst. Rev., 2015, (2), CD004493.

(Pénzes Melinda dr., Budapest, Üllói út 26., 1085 e-mail: melindapenzes@gmail.com)

\section{Tisztelt Szerzőink, Olvasóink!}

Az Orvosi Hetilapban megjelenő/megjelent közlemények elérhetőségére több lehetőség kínálkozik.

Rendelhető különlenyomat, melynek áráról bővebben a www.akkrt.hu honlapon (Folyóirat Szerzőknek, Különlenyomat menüpont alatt) vagy Szerkesztöségünkben tájékozódhatnak.

A közlemények megvásárolhatók pdf-formátumban is, illetve igényelhetö Optional Open Article (www.oopenart.com).

Adott dij ellenében az online közlemények bárki számára hozzáférhetök honlapunkon (a közlemények külön linket kapnak, így más oldalról is linkelhetővé válnak).

Bővebb információ a hirdetes@akkrt.hu címen vagy különlenyomat rendelése esetén a Szerkesztőségtől kérhető. 